\title{
Enhancing Eco-design methods using TRIZ Tools The case of ECOFAIRE
}

\author{
Fatima Zahra BEN MOUSSA ${ }^{\text {a }}$, Fatima Ezzahra ESSABER ${ }^{\mathrm{a}}$, Rachid \\ BENMOUSSA $^{\mathrm{a}}$, Sébastien DUBOIS ${ }^{\mathrm{b}}$ \\ ${ }^{a}$ SyLPRO / ENSA Marrakech, University of Cadi Ayyad Marrakech -Morocco \\ ${ }^{b}$ LGECO / INSA Strasbourg, Strasbourg - France
}

\begin{abstract}
:
Green design is a relevant research topic because of the need of powerful and confirmed systematic methods that can support companies in their efforts to develop green products within acceptable time and costs.

TRIZ, as a theory of invention problem-solving has proven its effectiveness in stimulating designer's creativity in several areas. Therefore, the main research question we address in this research is the following: how can TRIZ tools enhance the ideality of green-design methods?

This paper presents an exploratory analysis of this question. First, our methodology aims to study the weakness of an open Eco-design method known as ECOFAIRE using a general problem solving methods characterization. Then, it attempts to enhance the ideality of ECOFAIRE through a reverse engineering process that has been applied to an eco-product known as Ecodistrib. As a result, ECOFAIRE's ideality improvement assumptions with TRIZ tools are derived. The conclusion presents some perspectives to validate these assumptions and move towards a systematic approach for Ecodesign based on ECOFAIRE.
\end{abstract}

\section{Introduction}

Fast industrial growth and technological advances have recently raised many environmental concerns. As a result, industrial companies are expected to become more environmentally responsible and reduce their negative environmental impact by applying new technologies and especially by delivering eco-friendly products. Additionally, environmental regulations developed recently by the European Union called energy using product have motivated engineers and designers to more heavily focus on how to create more environmentally friendly products.

Several methods exist for eco-design, to assess and improve environmental impacts. [1]. The International Organization for Standardization ISO issued numerous norms, guidelines, and tools. For example, the ISO14040:2006 describes the principles and framework for life cycle assessment (LCA), ISO14044:2006 provides LCA guidelines, and ISO14006:2011 provides guidelines to implement Eco-Design as part of an environmental management system (EMS) within companies. A number of methods and tools have been developed to support the process of eco-innovation in the last two decades. To the best-known methods belong Eco-Compass, Life Cycle Design Strategy (LiDS Wheel), Sustainability Circle, EcoDesign PILOT, Eco-Ideation Tool, Value Mapping Tool, Design for Environment (DfE) and Quality Function Deployment for Environment (QFDE), EcoASIT, Eco-ideation stimulation mesomechanisms ESMs, Green Engineering with 12 Principles of Green Engineering, and other methods, presented in a comparative study of strategy and ideation-oriented ecoinnovation tools [2]. In the field of process engineering should be mentioned in first place Green Process Engineering and Process Intensification (PI), Process Design for Sustainability (PDfS), and other approaches.

However, green design remains a relevant research topic because of the lack of powerful and confirmed systematic methods that can support companies in their efforts to develop green products within acceptable time and costs.

To overcome this lack, several works have addressed this issue. We focus in this paper on the ones that deal with TRIZ (a Russian acronym of "Theory of Inventive Problem Solving''). TRIZ, as a theory for inventive problem resolution has proven its effectiveness in stimulating designer's creativity in several areas. In green design, 
several TRIZ utilization attempts exist. The references [1], [2] and [3] have largely addressed this issue.

With regard to eco-innovation, the authors in [1] defines primary and secondary eco-engineering contradictions and conceptualizes a correlation matrix between the eco-requirements for prediction of typical eco-contradictions in the field of processes involving solids handling. The implementation of eco-friendly solutions often causes secondary problems, and the application of the TRIZ-based approaches helps to identify these secondary problems, to predict and creatively solve eco-contradictions in advance, without efficiency losses. Additionally, a set of 20 TRIZ inventive principles most frequently used in environmental innovation was extracted from an analysis of a large number of patent and a process intensification technologies. The paper [2] focuses on the comparison of the ideation mechanisms during the ecoideation phase, to help users generate relevant ideas with a strong potential of environmental impact reduction. In addition to that, some case studies are performed to compare the adapted creativity tool for eco-innovation, regarding its performance.

This research also validated the need to place greater emphasis on the ideation phase in the process of eco-innovation. Indeed, environmental knowledge, ideation mechanisms and the structuring of the session are interdependent factors to consider in order to optimize the eco-ideation session and to be closer to the industrial reality. The paper [3] presents a systemic literature review of TRIZ use in eco-design. Indeed, the paper provides information about what is currently performed in connection to creativity methods, when TRIZ is combined with LCA, LCE Eco-efficiency and other integrated methods for eco-design process.

Despite of all of the existing scientific contribution of TRIZ in eco-innovation summarized above, the literature doesn't show the existence of a powerful and systematic approach to green design. Therefore, the main research question we address is the following: "How can TRIZ tools enhance the ideality of green-design methods?".

To deal with this question, the paper aims to present a first exploratory analysis of the contribution of TRIZ tools to green design methods systematization based on a case study. In fact, the main goal of this study is to analyze ECOFAIRE in order to improve its ideality through TRIZ tools utilization. ECOFAIRE is a method proposed by the Ecodesign groups of the ECOFAIRE program. It has been proposed as a guide to promote and facilitate the integration of eco-design in small and medium-sized businesses in any sector of activity [4].

Our methodology is to study a green designed product known as Ecodistrib and to define how ECOFAIRE could have been used by anticipation in the ecological design process using TRIZ tools in the phases suffering from methodological lack. As a result, this study will lead to a first formulation of "TRIZ-ECOFAIRE", a systematic approach to ecological products design based on ECOFAIRE and TRIZ Tools.

The remainder of this paper is organized as follows. Section 2 introduces the background, including the TRIZ originality for problem solving, TRIZ in eco-design, Problem solving Methods characterization, and the ECOFAIRE method characterization. Section 3 presents a reverse engineering process applied to an ecoproduct known as Ecodistrib in order to enhance the ideality of ECOFAIRE. Section 4 presents the different hypotheses of the first formulation of Triz-ECOFAIRE methodology. A conclusion and perspectives are provided in section 5

\section{Background}

\subsection{TRIZ originality for problem resolution}

TRIZ (Theory of Inventive Problem Solving), developed by Genrich Altshuller, is a problem-solving, analysis and forecasting theory derived from the study of patterns of invention in the patent literature. TRIZ was developed to assist engineers to systematically solve product design problems and develop next-generation technologies and products with less risk. TRIZ is an organized theory for problem solving, which can be applied for eco-design. Altshuller stated that TRIZ can be aimed for minimizing energy requirements, as well as complexity of engineering products. 
There are some key concepts which make TRIZ very valuable for innovative design:

- Ideality, describes the technical system development direction. The ideal final result (IFR) of eco-products is to perform desired functions without any environmental impacts. Therefore, looking at eco-innovative design problems of products from an ideal final result perspective is usually a very good first step towards success.

- Resources, are all the means used in a system or its environment, to improve its overall performance. Identifying and using resources in a TRIZ approach can bring new ideas and effectively solve the problem, so as to get closer to the final ideal result.

- Contradiction, helps to eliminate the contradiction and avoid the conventional tradeoffs. Their exist two levels of formulation of the contradiction: the contradiction known as the "technical contradiction" (TC), which expresses the opposition between two evaluation parameters (EP) of a system, and the "physical contradiction" (PC) that defines two states for the system's action parameter (AP), satisfying each of its conflicting objectives.

- Laws of evolution of technical systems, provides a means to reveal how systems evolve, predict the directions of evolve, and ultimately control the evolution.

In addition, The TRIZ theory includes methods for problem analysis and idea generation. These methods and tools can be classified according to three different categories:

- Tools for overcoming psychological inertia. The objective of these tools is to overcome the rigidity in the way of thought, and confinement of creativity in a certain pattern of thinking. Several tools for releasing psychological inertia are available in TRIZ, we can mention among them: (1) the nine-screen method (multi-screen vision), (2) Dimension-Time-Cost operators, and (3) smart little men method.

- Tools for solving technical and physical contradictions. Several methods and tools were created by Genrich Altshuller to solve the different types of contradictions, and to guide the designer towards generic solutions, as (1) the Matrix of solving technical contradictions, (2) the 40 inventive principles to solve technical contradictions, and (3) the 11 separation principles to solve physical contradictions.

- Standard solutions for solving system problems without the need of identifying contradictions. They are usually applied to correct the undesired interaction between two parts of a system.

\subsection{TRIZ in eco-design}

In the existing literature, a significant number of methods and proposals of integrating TRIZ with eco-design methods are proposed. As stated in the previous section, TRIZ is an organized method for problem solving, which is considered as supporting ideation and creativity component of eco-innovation and eco-design. TRIZ can be also used for minimizing energy requirements, as well as complexity of engineering environmentally friendly products [5], [6]. To comply with this purpose, several works are proposed in scientific literature dealing with the combination or the integration of TRIZ with other eco-design techniques, such as life Cycle Assessment (LCA), QFD (Quality Function Deployment) and CBR (Case Based Reasoning) to help designers achieve easily environmental design objectives. For example, in [7], an approach based on the integration of LCA, and eco-design guidelines converge in an integrated design for environment methodology. Rather new models have been developed to integrate the TRIZ theory and existing eco-design tools, with the aim of facilitating eco innovative product design. In [8], the author mentions an experiment within eco-design, and proposed a design methodology to support environmentally consciousness design of products by the integration of LCA, QFD, and TRIZ. The above- mentioned ideas are further developed in [9], which suggests the combination of QFD and TRIZ for an improved product life cycle management that supports knowledge codification and reuse. Another methodology is also presented in [10], that integrates the CBR and TRIZ methods is proposed. CBR can obtain the desired functional characteristics of a new design in an efficient way, and the TRIZ method 
ensures that designers can easily achieve design objectives due to the techniques provided by different technology fields. In [11], the authors elaborated an evolution of this approach and suggested integrating the TRIZ and CRB methods with Simplified LCA(s). In [12] the authors proposed an approach based on the integration of LCA and TRIZ eco guidelines, with the aim of supporting the implementation of the ecodesign approach in small and medium European enterprises. The application of TRIZ eco guidelines help to develop alternatives or modifications to a given system to reduce its environmental impact. Finally, the last example of this application of TRIZ can be found in [13], where the authors developed an ARIZ based on the Life cycle engineering (LCE) model, to implement the eco-designs of products.

In addition to the synergetic application of TRIZ with eco-design tools, the scientific literature provides also papers that proposed an adaptation of TRIZ methods or tools to eco-design domain. For example, in [14] the authors formulated and linked the seven eco-friendly elements developed by the World Business Council for Sustainable Development (WBCSD) for green product design to the inventive principles to construct a new table for inventive principles. In [10], [11], two different methods for green product design are proposed. The first is based on the application of inventive principles with laws of evolution and the principle of Ideality to help designers focus on concepts that minimize energy requirements and the complexity of engineering products. The second one is based on the laws of evolution of TRIZ to develop innovative approaches to solve design problems. In a similar manner, [15] propose a step by step procedure based on the application of the Laws of evolution, substance field resources, ideality and the technical contradictions, to solve problems related to green product design. Another example which establishes the link between ecoefficiency and laws of evolution is presented in [16], where the authors present an innovative methodology to help designers to predict technological evolutions for more environmentally friendly products, by identifying the relationship between the strategies of the Eco-Design Strategy Wheel and the TRIZ evolution trends.

\subsection{Problem solving Methods characterization}

There are several standard techniques to search for a solution: non-systematic research techniques known as «Brainstorming»; Systematic research techniques also called "Systematic trials and errors" and systematic analysis of the problematic situation. Unlike the first two techniques, finding solutions in "Systematic analysis of the problematic situation" techniques are based on search space reducing. In this approach, the question that arises globally is "WHY does the problem exist?" and we try to develop or converge towards the solution by reducing the search space by answering this question. The model type of these techniques involves the following steps:

1. "Recognize the problem": consists of understanding the problem, knowing exactly where the problem lies, or measuring the problem, etc.

2. "Analyze the problem": tries to answer various questions to understand why the problem exists, what are the causes of the problem, what are the parameters and the factors that influence the problem, what is the desired result to eliminate the problem, etc.

3. "Synthesize Solution Concepts": formulates solution ideas called also conceptual solutions (to clearly distinguish from technical solutions).

4. "Concretize the solutions" seeks to transform the idea of solution or the conceptual solution into a concrete and applicable technical solution to solve the problem posed in the first step.

5. Logically the last step seeks to "evaluate the technical solutions" developed.

In general, each solution research method can be characterized by comparison of its flow logic with the model-type steps presented previously.

Indeed, the use of the table 1 makes it possible to identify, for the considered method, the steps which correspond to the "recognition of the problem", "the analysis of the problem", "the identification of the conceptual solution", " the implementation of the solution "on the technical or application level as well as the evaluation of the solution. The tools used in each step are also identified. Also, by analyzing the tools used in each step of the considered method, we can deduce its nature and decide whether it is Unstructured, Semi Structured or Structured. 
An unstructured step is performed randomly. His success depends heavily on analyst skill and know-how. The result obtained is uncertain and subjective.

A step described as semi structured one relies on reasoning and a precise logic to converge towards the desired result. It has a kind of roadmap to follow. However, the phases of this reasoning logic taken in isolation are unstructured. They do not operate the logic of reducing search space.

Conversely, a step described as Structured relies on a reasoning and a precise logic that makes it possible to converge towards the desired result in an algorithmic way. The reasoning could be based on a knowledge base, a set of good practices or any other type of expert systems. The result thus depends on the quality of the available knowledge and not only the analyst's know-how.

To conclude, if we analyze the nature of the steps of any problem solving method, we can deduce the standard technique to which it belongs and its capacity to provide original and quality solutions. Thus, a problem-solving method that has all the steps of the model-type (whether these steps are structured or not) is a "Systematic analysis of the problematic situation" method. A method that does not have the "Analyze the problem" step is either "non-systematic" method (brainstorming), or "systematic" (Trials and Errors) one. It depends on how the "Synthesize Solution Concepts" step unfolds. A method that has "unstructured" steps is of lower quality, it can be improved. The ideal method has all its stages structured. Thus, each method can evolve towards its ideality by improving the quality of its stages.

\subsection{The ECOFAIRE methodology}

ECOFAIRE presentation. The French ECOFAIRE program was organized and conducted by SEM Pays de Loire in collaboration with the environmental consulting firm EVEA between 2006 and 2008 [4].This program aims to "promote and facilitate the development of environmentally friendly products". A collaborative study was conducted with companies, industrial designers and engineers. The methodological tool ECOFAIRE is part of this research work. It is composed of two introductory sheets followed by 18 others, to be used in five chronological stages: "Scope and stakes", "Initial environmental assessment", "Solution search", "Evaluation of solutions", "Results and communication". Non-expert users are targeted here, whether they belong to industry or academia. On this paper, 9 analysis approaches are used. The E1 (3.1) approach proposes an analysis allowing a reference product to be assessed on six aspects combining life cycle thinking specially and environmental impacts to get a better review about it [2]. Concerning the E2 (3.1), this approach takes stock of the different phases raised during cycle E1 in a way to detect the environmental issues related to each stage with its risk of impact which depends of the stage and its stakes. E7 / E8 approach (3.1) aims to identify and prioritize the aspects and impacts of each level of the end-of-life cycle of a reference product according to a ranking and motivations. About the ES1/ES2/ES3 (3.5), they allow to establish a comparison of solutions according to environmental indicators between a product and a reference product to get a view of the environmental consequences using ES2 wich is a DSI (Decision Support Instrument) while the ES2 is a visualization medium. R1 and R2 (3.3), allows to search for solutions by establishing an idea about different design choices that we can make by each level as well as the source of the solution. The operation of "Solution search" relies on "Synthesizing solution concepts" by the Eco design wheel (R1) and the checklist (R2).

ECOFAIRE characterization. If we analyze the ECOFAIRE method, we notice that:

1. "Environmental Assessment of Product Reference" coincides well with the step "recognize the problem" using "R1, R2, E7/8" forms.

2. "Solution search" is consistent with "Synthesizing solution concepts" using the Eco design wheel (R1) and the checklist (R2).

3. "Evaluate the technical solution" coincides well with the step "recognize the problem" using the "ES1, ES2, ES3" forms

4. The steps "Analyze the problem" and "Realize the solutions" of the model-type are not covered by ECOFORM

If we analyze the nature of the steps covered by the ECOFAIRE method, we notice that they are semi-structured because the analyst has a roadmap consisting of a 
multitude of forms and tools that guide him to identify solutions. But the answer provided in each form is subjective and strongly depends on the analyst's know-how.

The analysis of the table 1 shows that the ECOFAIRE Model belongs to "Systematic Analysis of the Problematic Situation" techniques. The fact that some of its stages are not covered and that those covered are semi-structured, ECOFAIRE is not a complete method for Eco design problem solving that can insure original quality solutions.

Table 1: characterization of ECOFAIRE method

\begin{tabular}{|c|c|c|c|c|c|}
\hline $\begin{array}{l}\text { Model- } \\
\text { Type } \\
\text { steps }\end{array}$ & $\begin{array}{l}\text { Recognize the } \\
\text { problem }\end{array}$ & $\begin{array}{l}\text { Analyze } \\
\text { the } \\
\text { problem }\end{array}$ & $\begin{array}{l}\text { Synthesize } \\
\text { Solution } \\
\text { Concepts }\end{array}$ & $\begin{array}{l}\text { Concretize } \\
\text { the } \\
\text { solutions }\end{array}$ & $\begin{array}{l}\text { Evaluate the } \\
\text { technical } \\
\text { solutions }\end{array}$ \\
\hline $\begin{array}{l}\text { Ecofaire } \\
\text { steps }\end{array}$ & $\begin{array}{l}\text { Environmental } \\
\text { Assessment of the } \\
\text { RP }\end{array}$ & None & $\begin{array}{l}\text { Search for } \\
\text { solutions }\end{array}$ & None & $\begin{array}{l}\text { Evaluation of } \\
\text { the envisaged } \\
\text { solutions }\end{array}$ \\
\hline $\begin{array}{l}\text { Ecofaire } \\
\text { tools }\end{array}$ & $\begin{array}{l}\text { CE4: } \\
\text { environmental } \\
\text { expectations and } \\
\text { requirements of } \\
\text { the different } \\
\text { actors } \\
\boldsymbol{E} 1 \text { : Life cycle } \\
\text { description in first } \\
\text { approach of the } \\
\text { reference product } \\
\boldsymbol{E 2 :} \\
\text { Environmental } \\
\text { issues as a first } \\
\text { step } \\
\boldsymbol{E 7} / \boldsymbol{E} 8 \text { : } \\
\text { Identification and } \\
\text { characterization } \\
\text { of environmental } \\
\text { aspects }\end{array}$ & $\begin{array}{l}\text { No tool } \\
\text { available }\end{array}$ & $\begin{array}{l}\text { R1: Eco- } \\
\text { design } \\
\text { wheel } \\
\text { R2: Check } \\
\text { list }\end{array}$ & No tools & $\begin{array}{l}\text { ES1: } \\
\text { comparison of } \\
\text { solutions } \\
\text { according to } \\
\text { environmental } \\
\text { indicators } \\
\boldsymbol{E S} 2: \text { decision } \\
\text { support } \boldsymbol{E S 3 :} \\
\text { visualization } \\
\text { of the } \\
\text { environmental } \\
\text { consequences } \\
\text { of design } \\
\text { choices }\end{array}$ \\
\hline Nature & Semi structured & - & $\begin{array}{l}\text { Semi } \\
\text { structured }\end{array}$ & - & $\begin{array}{l}\text { Semi } \\
\text { structured }\end{array}$ \\
\hline
\end{tabular}

\section{Towards Triz-EcoFaire: a case study: « Ecodistrib »}

Ecodistrib is a distributor of different types of liquid detergents installed in supermarkets to replace the act of purchasing cans of disposable detergents. This case is available on the following link: https://www.ecoconception.fr/exemples/h/eco2distrib-ecodistributeur.html

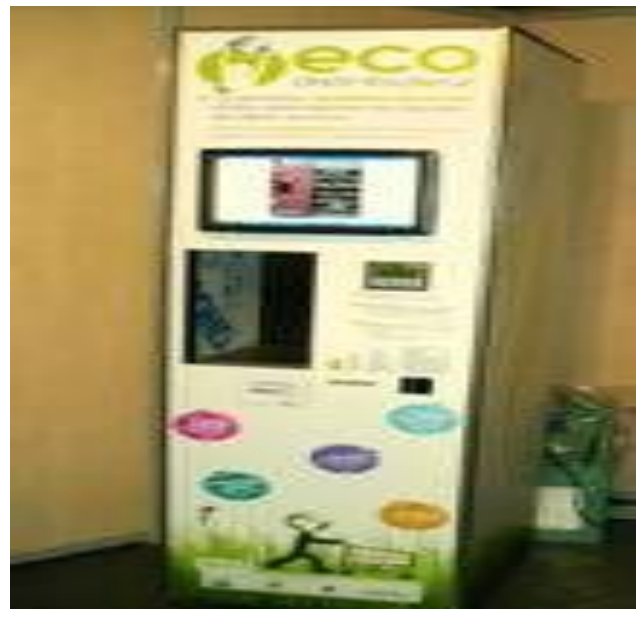

Figure 1: Ecodistrib 


\subsection{Recognize the problem}

This step consists of rolling out the CE4, E1, E2 and E7 / E8 forms for the reference product: Detergent bottle.

Table 2: Expectations and environmental requirements (CE4)

\begin{tabular}{|c|c|}
\hline Chain of actors & $\begin{array}{l}\text { Expectations and environmental requirements } \\
\text { Specify whether explicit or implicit (= not formulated, } \\
\text { or assumed) }\end{array}$ \\
\hline Suppliers & \\
\hline $\begin{array}{l}\text { Transport and logistics } \\
\text { subcontractors }\end{array}$ & Less packaging to ship \\
\hline $\begin{array}{l}\text { Top management of the } \\
\text { company }\end{array}$ & Cost reduction \\
\hline $\begin{array}{l}\text { Departments of the } \\
\text { company (marketing, BE, } \\
\text { employees, ...) }\end{array}$ & Manufacturing: less packaging, gain energy \\
\hline $\begin{array}{l}\text { Clients, Specifiers, Other } \\
\text { intermediaries }\end{array}$ & $\begin{array}{l}\text { Super and hypermarkets: brand image, show } \\
\text { implication in DD }\end{array}$ \\
\hline End users & Eco-freindly products \\
\hline
\end{tabular}

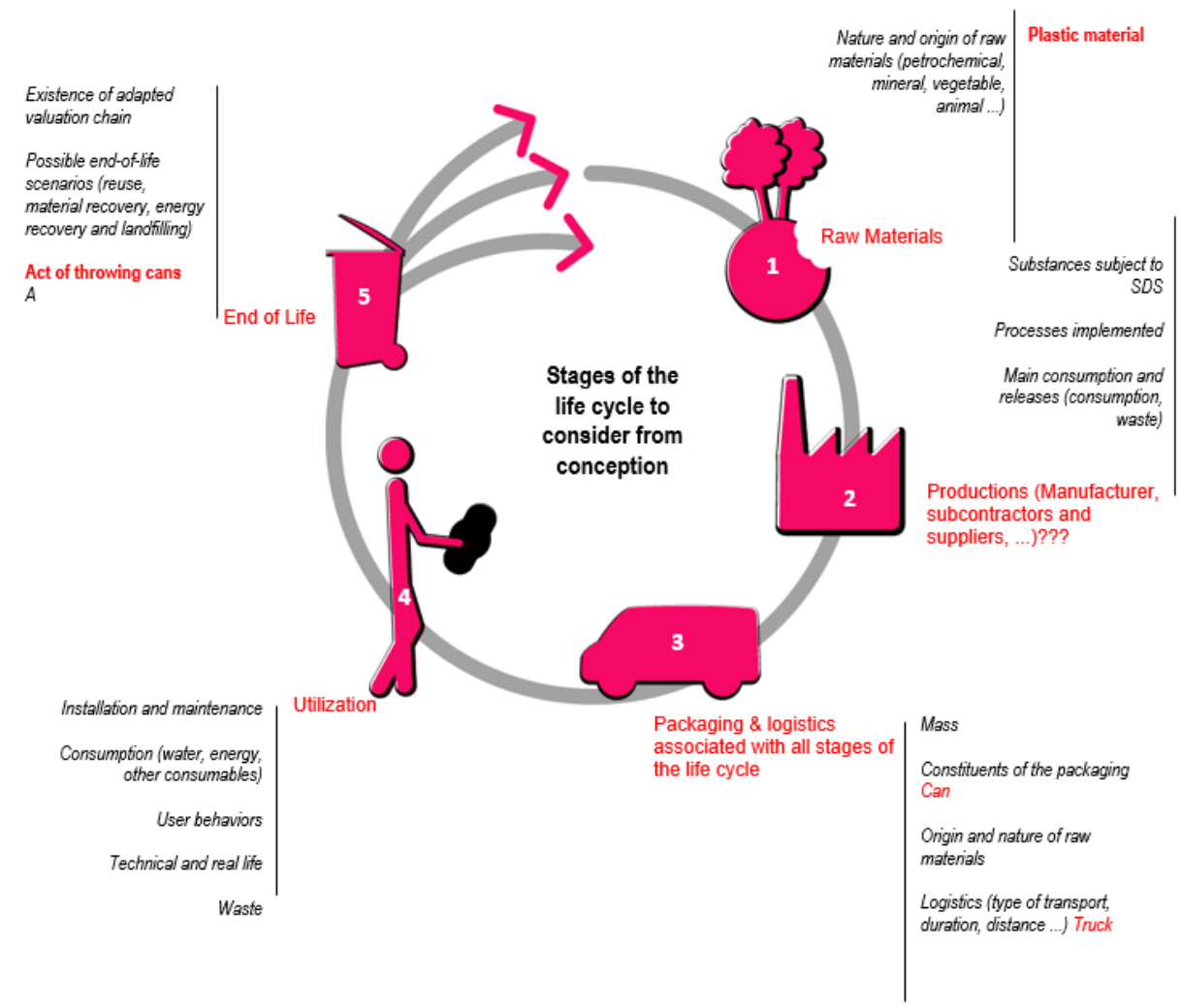

Figure 2: Life cycle analysis of the reference product (E1) 
Table 3: Environmental issues (E2)

\begin{tabular}{|c|c|c|c|c|c|c|}
\hline \multirow{2}{*}{ Étapes } & \multirow{2}{*}{$\begin{array}{l}\text { Environmental issues of the } \\
\text { product }\end{array}$} & \multicolumn{4}{|c|}{ Risk of impacts } & \multirow[b]{2}{*}{ Your details, comments } \\
\hline & & $\overline{-}$ & $\dot{-}$ & \begin{tabular}{|c|}
+ \\
Good
\end{tabular} & $?$ & \\
\hline \multirow{4}{*}{$\begin{array}{l}1 \text { - Raw } \\
\text { Materials }\end{array}$} & $\begin{array}{l}\text { Preservation of resources: Use of a threatened or limited } \\
\text { rescource (primary forests, oil ...) }\end{array}$ & - & & & & \\
\hline & Recycled source material & & & & & \\
\hline & Origin of materials (distance and optomized means of tansport) & & & & & \\
\hline & $\ldots$ & & & & & \\
\hline \multirow{4}{*}{$\begin{array}{l}2 \text { - Productions } \\
\text { - Subcontractons/ } \\
\text { suppliers } \\
\text { - Maker } \\
\end{array}$} & Poluting processes & & & & & \\
\hline & Hazerdous construction waste, non-recyclable waste & & & & & \\
\hline & Geograprical stiuabion (local, national ... for suocontractors & & & & & \\
\hline & $\ldots$ & & & & & \\
\hline \multirow[t]{5}{*}{ 3a-Packaging } & Optimized packaging in mass or voume & & & & & \\
\hline & Reusable packaging & -- & & & & \\
\hline & Shutte packaging _.. & & & & & \\
\hline & Packaging integrating recovery channels for recovery & & & & & \\
\hline & $\ldots$ & & & & & \\
\hline \multirow[t]{4}{*}{ 3b- Logistics } & Optimized logistics (distances, filing, ful returns ...) & & & & & \\
\hline & $\begin{array}{l}\text { Types of transport (combined rai-road, fuvial, maritime, Euro V } \\
\text { standard trucks...) }\end{array}$ & & & & & \\
\hline & Recovery during deivery: user products, packsging ... & & & & & \\
\hline & $\ldots$ & & & & & \\
\hline \multirow[t]{8}{*}{4 - Utilization } & Consumption of energy, water ... & & & & & \\
\hline & Using consumbbles & & & & & \\
\hline & Features tailored to user needs & & & & & \\
\hline & Waste procuction & & & & & \\
\hline & User information and awareness & & & & & \\
\hline & Life adapted to the reality of use and technological developpments & & & & & \\
\hline & Oner [nujances, emissions ...] & & & & & \\
\hline & $\ldots$ & & & & & \\
\hline \multirow{3}{*}{ 5- End of Life } & $\begin{array}{l}\text { Recyclable (existing channels AND possioility of diemanting the } \\
\text { product for distroution in the sectors) }\end{array}$ & - & & & & \\
\hline & No "clean-up" of the product needed before recovery & - & & & & \\
\hline & $\ldots$ & & & & & \\
\hline
\end{tabular}

Table 4: identification and prioritization of aspects and impacts (E7/E8)

\begin{tabular}{|c|c|c|c|l|}
\hline & $\begin{array}{c}\text { Aspects or } \\
\text { impacts } \\
\text { steps involved }\end{array}$ & $\begin{array}{c}\text { Ranking } \\
\text { Very } \\
\text { important } \\
\text { Important } \\
\text { Secondary }\end{array}$ & $\begin{array}{c}\text { Ranking } \\
\text { motivations }\end{array}$ \\
\hline A & $\begin{array}{c}\text { Non-renewable } \\
\text { resources }\end{array}$ & Raw materiel & $\begin{array}{c}\text { Very } \\
\text { important }\end{array}$ & $\begin{array}{l}\text { Extraction raw } \\
\text { material for } \\
\text { packaging }\end{array}$ \\
\hline B & $\begin{array}{c}\text { Energy } \\
\text { consumption }\end{array}$ & Production & $\begin{array}{c}\text { Very } \\
\text { important }\end{array}$ & $\begin{array}{l}\text { Manufacturing } \\
\text { packaging }\end{array}$ \\
\hline C & $\begin{array}{c}\text { Non-renewable } \\
\text { resources }\end{array}$ & Packaging & $\begin{array}{c}\text { Very } \\
\text { important }\end{array}$ & $\begin{array}{l}\text { Packing volume / } \\
\text { liquid quantity }\end{array}$ \\
\hline D & $\begin{array}{c}\text { Pollution } \\
\text { important }\end{array}$ & $\begin{array}{l}\text { Transmission } \\
\text { Distance of Cans }\end{array}$ \\
\hline E & $\begin{array}{c}\text { Non-renewable } \\
\text { resources }\end{array}$ & End of life & $\begin{array}{c}\text { Very } \\
\text { important }\end{array}$ & Act of throwing \\
\hline F & & & \multicolumn{2}{|l}{} \\
\hline
\end{tabular}




\begin{tabular}{|c|c|c|c|c|c|c|c|c|c|}
\hline \multirow[t]{6}{*}{ Front envilonment } & \multicolumn{4}{|c|}{ Sup'iser System : Enviloniment/Use } & & \multicolumn{4}{|c|}{ Evolutions Environnment / Use } \\
\hline & & \multicolumn{3}{|c|}{ Stakeholders } & & \multicolumn{4}{|c|}{ Stakeholders } \\
\hline & distributors & \multicolumn{3}{|c|}{ hypermarket, Neighlogorhood Distributor } & distributors & \multicolumn{4}{|c|}{ Show its envirommental implications and improve its imgage } \\
\hline & manufocturers & \multicolumn{3}{|c|}{ Product,parckgaging,.... } & manufacturers & \multicolumn{4}{|c|}{ Less packagingto tomanufacture and ship, Energyg gain } \\
\hline & consumers & \multicolumn{3}{|c|}{ campany, particular ,... } & consumers & \multicolumn{4}{|c|}{ Avertis, nature:firiendly products } \\
\hline & arriers & & & & carriers & \multicolumn{4}{|c|}{ less packaging to mannufacture and ship } \\
\hline \multirow{10}{*}{ front system } & & \multicolumn{3}{|c|}{ System / completele lite cycle } & & \multicolumn{4}{|c|}{ System / completel lite cycle Future } \\
\hline & \multicolumn{4}{|c|}{ Referencice Product/Service: Liquid Detergents } & & \multicolumn{4}{|c|}{ Product Requirement/Service to be Developed } \\
\hline & Aspect//mpact & Lifecyde & Ranking & Motivation & Stakeholder & Distributors & Manufactureers & Consumer & Cariers \\
\hline & Non-renewable resources: & Raw & Vervimportant: & Raw moterial extraction for & Rawmaterial & & Clean raw miterial & & \\
\hline & Energy consumption & iproduction & Very important: & Raw moterial extraction for & Production & & & & \\
\hline & Nonrenewable resources & Packaging & Very important, & Volume of packaging / /liquid & Padkaging & & & & \\
\hline & \begin{tabular}{|l|} 
Pollution \\
\end{tabular} & Logistics & Very important & Transport Distance of Cans & Logistitis & & & & shortdilistance \\
\hline & Non-renewable resources & End of life & Very important: & Actoffthrowing & use & & Removoble product & & \\
\hline & ... & & & & End of lithe & & obscolesence NP & Reuse the packaging & \\
\hline & $\ldots$ & & & & $=$ & & & & \\
\hline & & & & & & & & & \\
\hline \multirow[t]{7}{*}{ front sub-system } & \multicolumn{4}{|c|}{ Sub System / Components } & & \multicolumn{4}{|c|}{ Sub System / Components of Tomorrow } \\
\hline & Raw moterial & \multicolumn{3}{|c|}{ Plastic,,$\ldots$} & Row moterial & \multicolumn{4}{|c|}{ Clean raw miterial } \\
\hline & Production & & & & Production & \multicolumn{4}{|c|}{ Clean technology.... } \\
\hline & Packaging & \multicolumn{3}{|c|}{ Plassic bottle } & Packoging & & & & \\
\hline & Logistics & \multicolumn{3}{|c|}{ trucks, } & Logiticis & \multicolumn{4}{|c|}{ Multi modod transsoot, reverese: logisitics } \\
\hline & use & & & & use & & & & \\
\hline & End of life & \multicolumn{3}{|c|}{ Actof Discard/ Dischargege } & End of life & \multicolumn{4}{|c|}{ Newregulations } \\
\hline
\end{tabular}

Figure 3: 9 Screens tool

\subsection{Analyze the problem}

ECOFAIRE doesn't present any tool for problematic analysis situation. We propose to use for this issue the TRIZ contradiction system. Thus, the main contradiction resolved by Ecodistrib is the following:

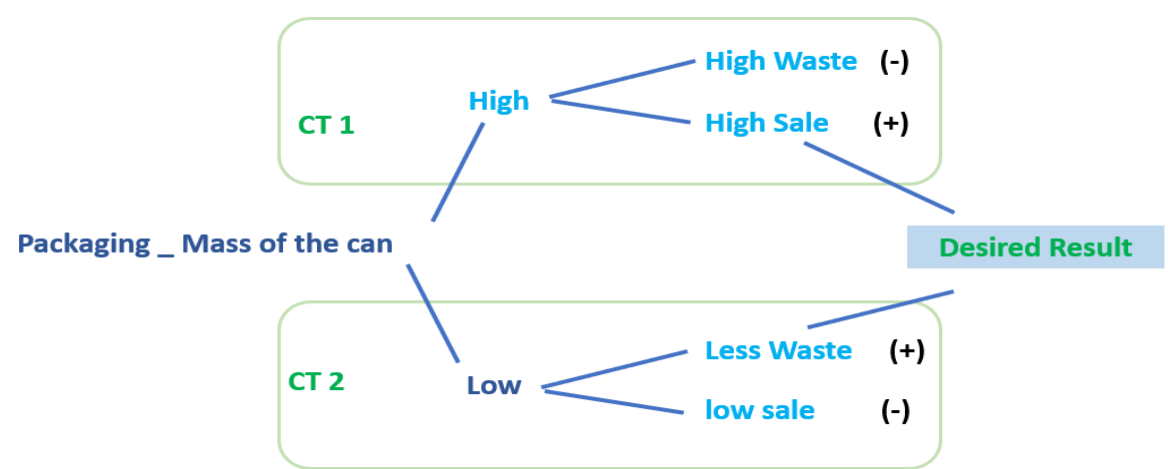

Figure 4: the system of contradictions of EcoDistrib

\subsection{Synthesize Solution Concepts}

The search for solutions by ECOFAIRE's tools R1 and R2, allows drawing up the following table. This table presents the different design choices considered in EcoDistrib by stage of the life cycle as well as the source of the solution.

Table 5: source of choices made in EcoDistrib

\begin{tabular}{|c|c|c|c|c|}
\hline $\begin{array}{c}\text { Design } \\
\text { Choice }\end{array}$ & Production & $\begin{array}{c}\text { Packaging } \\
\text { Logistics }\end{array}$ & End use & End of life \\
\hline Demountable & None & & $\begin{array}{c}\text { R1: Lifespan / } \\
\text { Adapted / } \\
\text { Evolution / } \\
\text { Modular }\end{array}$ & \\
\hline
\end{tabular}




\begin{tabular}{|c|c|c|c|}
\hline $\begin{array}{l}\text { Unplanned } \\
\text { obsolescence }\end{array}$ & & $\begin{array}{l}\text { R1: lifetime / long } \\
\text { since the start }\end{array}$ & \\
\hline $\begin{array}{l}\text { Close } \\
\text { production } \\
\text { place } \\
\end{array}$ & $\begin{array}{l}\text { R1 : transport / } \\
\text { Proximity }\end{array}$ & & \\
\hline \multicolumn{4}{|l|}{$\begin{array}{l}\text { Reusable } \\
\text { packaging }\end{array}$} \\
\hline $\begin{array}{l}\text { Close place of } \\
\text { distribution }\end{array}$ & $\begin{array}{l}\text { R1 : transport / } \\
\text { Proximity }\end{array}$ & & \\
\hline $\begin{array}{l}\text { Distribution } \\
\text { system }\end{array}$ & & $\begin{array}{l}\text { R1 : consumption } \\
\text { / standby mode }\end{array}$ & \\
\hline $\begin{array}{l}\text { Recoverable } \\
\text { material }\end{array}$ & & & $\begin{array}{c}\mathrm{R} 1: \\
\text { Valorization / } \\
\text { incineration / } \\
\text { energy } \\
\text { recovery } \\
\end{array}$ \\
\hline $\begin{array}{l}\text { Local raw } \\
\text { material } \\
\text { source }\end{array}$ & $\begin{array}{l}\text { R1 : transport / } \\
\text { Proximity }\end{array}$ & & \\
\hline Sealing & & - & \\
\hline Energy source & & $\begin{array}{l}\text { R1 : Consumption } \\
\text { / Energy / saved }\end{array}$ & \\
\hline
\end{tabular}

Two remarks emerge from the use of these two tools:

- The difficulty of using the R1 eco-design wheel. Indeed, this wheel doesn't give a procedure to choose the relevant principles. On the other hand, the list of solutions seems incomplete for the EcoDistrib case.

- The R2 checklist details the choices listed in R1. Its use is also difficult and does not aspire to trust, ...

The search for solutions by the traditional tools of the TRIZ doesn't seem to find the choices made in the case EcoDistrib. Indeed, the solution adopted to solve the technical contradiction is to replace the act of buying the liquid in a disposable packaging by the act of buying the liquid in a reusable packaging through a distributor to resolve the contradiction presented in the figure 4.

The two parameters of the technical contradiction do not correspond to any parameter of the classical TRIZ matrix. This seems unsuitable for use in the field of eco-design. The analysis of the solution adopted in the case of EcoDistrib shows that none of the 40 principles invented, nor principles of separation could be exploited to achieve it.

\subsection{Concretize the solutions}

According to a technical point of view, the purchase of the liquid is done by filling from a distributor. This solution could not have been generated by the use of traditional TRIZ tools such as effect pointers.

\subsection{Evaluate the technical solutions:}

The comparison between Ecodistrib and the reference product "Can" as well as the visualization of the environmental consequences of Ecodistrib are presented in forms ES1, ES2 and ES3 of ECOFAIRE.

Table 6: comparison of solutions according to environmental indicators (ES1)

\begin{tabular}{|l|c|c|}
\cline { 2 - 3 } \multicolumn{1}{c|}{} & $\begin{array}{c}\text { Reference product } \\
\text { Can }\end{array}$ & $\begin{array}{c}\text { Proposition 1 } \\
\text { Ecodistrib }\end{array}$ \\
\hline $\begin{array}{l}\text { Indicator 1 } \\
\text { Name : Waste Volume }\end{array}$ & Important & Low \\
\hline $\begin{array}{l}\text { Indicator } 2 \\
\text { Name : Energy consumption }\end{array}$ & Important & Low \\
\hline $\begin{array}{l}\text { Indicator 3 } \\
\text { Name : Pollution }\end{array}$ & Important & Low \\
\hline
\end{tabular}


Table 7: decision support (++ very important; + important; - week; -- very week)

(ES2)

\begin{tabular}{|l|c|c|c|}
\hline \multicolumn{1}{|c|}{ Solutions } & $\begin{array}{c}\text { Interests } \\
\text { Customers / Users }\end{array}$ & $\begin{array}{c}\text { Costs interest } \\
\text { and Feasibility }\end{array}$ & $\begin{array}{c}\text { Environment } \\
\text { interests }\end{array}$ \\
\hline Reference Product : Can & & & \\
\hline $\begin{array}{l}\text { Proposition 1 } \\
\text { Description : Ecodistrib }\end{array}$ & ++ & ++ & ++ \\
\hline
\end{tabular}

Table 8: visualization of the environmental consequences of design choices (ES3)

\begin{tabular}{|c|c|c|c|c|c|}
\hline $\begin{array}{c}\text { Conception } \\
\text { choice }\end{array}$ & Production & $\begin{array}{c}\text { Packaging } \\
\text { Logistics } \\
\end{array}$ & Use & $\begin{array}{c}\text { End of } \\
\text { life }\end{array}$ & $\begin{array}{l}\text { Consequences for } \\
\text { the environment }\end{array}$ \\
\hline Disassembly & $\begin{array}{l}\text { No final } \\
\text { assembly } \\
\text { (welds) }\end{array}$ & & $\begin{array}{c}\text { Repairable } \\
\text { and } \\
\text { evolutionary }\end{array}$ & & $\begin{array}{c}\text { Raw material } \\
\text { economy, life } \\
\text { extension }\end{array}$ \\
\hline $\begin{array}{l}\text { Unplanned } \\
\text { obsolescence }\end{array}$ & & & $\begin{array}{l}\text { Repairable } \\
\text { and } \\
\text { evolutionary }\end{array}$ & & $\begin{array}{l}\text { raw material } \\
\text { economy, life } \\
\text { extension }\end{array}$ \\
\hline $\begin{array}{l}\text { Close } \\
\text { production } \\
\text { area }\end{array}$ & & $\begin{array}{l}\text { Less } \\
\text { transport }\end{array}$ & & & $\begin{array}{c}\text { Energy saving } \\
\text { pollution }\end{array}$ \\
\hline $\begin{array}{l}\text { Reusable } \\
\text { packaging }\end{array}$ & & & & & $\begin{array}{c}\text { Raw material } \\
\text { economy }\end{array}$ \\
\hline $\begin{array}{l}\text { Close } \\
\text { production } \\
\text { area }\end{array}$ & & $\begin{array}{l}\text { Less } \\
\text { transport }\end{array}$ & & & $\begin{array}{l}\text { Energy saving, } \\
\text { pollution }\end{array}$ \\
\hline $\begin{array}{l}\text { Distribution } \\
\text { system }\end{array}$ & & & $\begin{array}{l}\text { Quantity } \\
\text { bought at } \\
\text { most fair }\end{array}$ & & Raw material saving \\
\hline $\begin{array}{l}\text { Recoverable } \\
\text { material }\end{array}$ & & & & $\begin{array}{l}\text { Energy } \\
\text { recovery }\end{array}$ & Raw material saving \\
\hline $\begin{array}{l}\text { Local raw } \\
\text { material } \\
\text { source }\end{array}$ & & $\begin{array}{l}\text { Less } \\
\text { transport }\end{array}$ & & & $\begin{array}{l}\text { Energy saving, } \\
\text { pollution }\end{array}$ \\
\hline Sealing & & & $\begin{array}{l}\text { No risk of } \\
\text { liquid loss }\end{array}$ & & $\begin{array}{l}\text { Nuisance man: } \\
\text { Cleanliness, raw } \\
\text { material saving }\end{array}$ \\
\hline $\begin{array}{l}\text { Energy } \\
\text { Source }\end{array}$ & & & Low Energy & & Energy saving \\
\hline
\end{tabular}

The use of EcoForm forms also leads to several remarks:

- It is necessary to conduct LCA (life cycle analysis) to arrive to quantified indicators for the ES1 form

- The evaluation of different interests in ES2 is qualitative

- Overall, despite their sufficiency to evaluate and compare eco-design solutions, ECOFAIRE documents are not structured because their uses depend on the analyst's competence.

\section{Hypotheses of First formulation of Triz-ECOFAIRE}

Conducting an inverse engineering analysis on the Ecodistrib case made it possible to identify a set of ECOFAIRE improvement hypotheses by the TRIZ tools. It also allowed to highlight a set of disadvantages compared to ECOFAIRE tools themselves.

The following table (table 9) explains how can ECOFAIRE enhance its ideality by introducing TRIZ Tools in its incomplete or lower quality steps. However, Triz tools need to be updated to fit within Eco design and ECOFAIRE context. We describe in the following, how each tool introduced has to be adapted. 


\subsection{H1: Multiscreen tool}

The multiscreen tool can play its classic role in predicting the future eco-designed system. But for that it must be adapted to include the synthesis of the documents of ECOFAIRE of the analysis phase (See figure 3) in particular:

- The expectations and environmental requirements of the various actors

- The description of the life cycle

- Environmental issues

- Identification of environmental aspects and impacts

\subsection{H2: System of contradiction}

The contradiction system of TRIZ keeps all its importance to really understand the problem and to reveal the desired result. However, the terms of the EPV Model must be adapted to the context of eco-design, as follows (figure 5):

- Element: must reflect a stage of the life cycle (raw material, logistics packaging and transport, production, use, end of life), ...

- Action Parameter: must reflect an environmental aspect from the context of the study. The environmental aspect is "an element of the activities, products or services of an organism likely to interact with the environment".

- Evaluation Parameter 1: Must reflect an Environmental Impact. The environmental impact is "any modification of the environment, negative or beneficial, resulting totally or partially from the environmental aspects of an organism" (Exhaustion of resources, damage to biodiversity, air pollution, water pollution, soil pollution, waste,...).

- Evaluation parameter 2: must reflect an important outcome indicator in the context of the study to assess economic performance (use parameter).
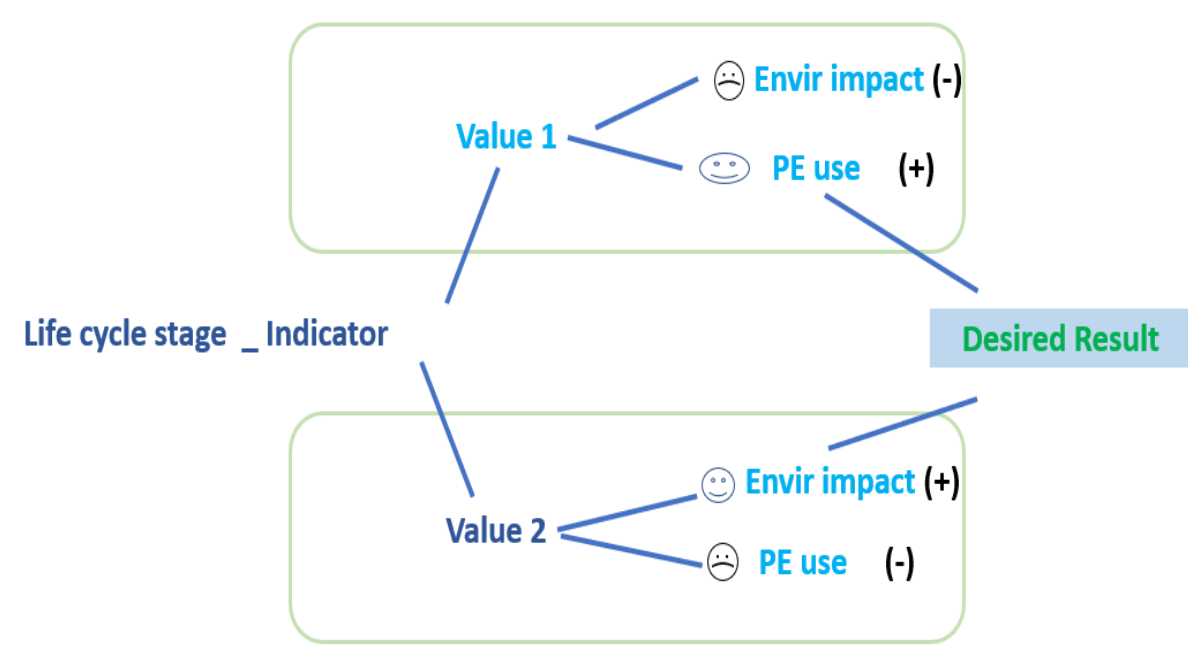

Figure 5: adaptation of the system of contradictions to the context of eco-design

\subsection{H3: Principals}

The principles of separation and the 40 inventive principles do not seem adaptable to the context. On the other hand, a new tool can be developed that links TRIZ's contradiction system to the principles stated in the R1 eco-design wheel and the R2 checklist.

\subsection{H4: Effects pointer}

The base of the physical effect pointer of Triz also seems unsuitable for the case of EcoDistrib. It would also be wise to develop an effect base specific to the context of Eco-design. 
Table 9: TRIZ-ECOFAIRE characterization

\begin{tabular}{|c|c|c|c|c|c|}
\hline $\begin{array}{c}\text { Model- } \\
\text { Type steps }\end{array}$ & Recognize the problem & $\begin{array}{c}\text { Analyze } \\
\text { the } \\
\text { problem }\end{array}$ & $\begin{array}{l}\text { Synthesize } \\
\text { Solution } \\
\text { Concepts }\end{array}$ & $\begin{array}{c}\text { Concretize } \\
\text { the } \\
\text { solutions }\end{array}$ & $\begin{array}{c}\text { Evaluate the } \\
\text { technical } \\
\text { solutions }\end{array}$ \\
\hline $\begin{array}{l}\text { Ecofaire } \\
\text { steps }\end{array}$ & $\begin{array}{c}\text { Environmental } \\
\text { Assessment of RP }\end{array}$ & None & $\begin{array}{l}\text { Searching } \\
\text { solutions }\end{array}$ & None & $\begin{array}{c}\text { Assessment of } \\
\text { the envisaged } \\
\text { solutions }\end{array}$ \\
\hline $\begin{array}{l}\text { Existing } \\
\text { Ecofaire } \\
\text { tools }\end{array}$ & $\begin{array}{l}\text { CE4: environmental } \\
\text { expectations and } \\
\text { requirements of the } \\
\text { different actors } \\
\boldsymbol{E} 1: \text { Life cycle } \\
\text { description in first } \\
\text { approach of the } \\
\text { reference product } \\
\boldsymbol{E} 2: \text { Environmental } \\
\text { issues as a first step } \\
\boldsymbol{E} 7 / \boldsymbol{E} \text { : Identification } \\
\text { and characterization of } \\
\text { environmental aspects }\end{array}$ & None & $\begin{array}{l}\text { R1: Eco- } \\
\text { design } \\
\text { wheel } \\
\text { R2: Check } \\
\text { list }\end{array}$ & None & $\begin{array}{l}\boldsymbol{E S 1} \text { : } \\
\text { comparison of } \\
\text { solutions } \\
\text { according to } \\
\text { environmental } \\
\text { indicators } \\
\boldsymbol{E S} 2 \text { : decision } \\
\text { support } \\
\boldsymbol{E S 3 :} \\
\text { visualization } \\
\text { of the } \\
\text { environmental } \\
\text { consequences } \\
\text { of design } \\
\text { choices }\end{array}$ \\
\hline $\begin{array}{c}\text { Improvem } \\
\text { ent by } \\
\text { TRIZ }\end{array}$ & $\begin{array}{c}\text { Adapt the } 9 \text { screens } \\
\text { tool }\end{array}$ & $\begin{array}{l}\text { Adapt the } \\
\text { system of } \\
\text { contradict } \\
\text { ions }\end{array}$ & $\begin{array}{c}\text { To } \\
\text { develop }\end{array}$ & $\begin{array}{c}\text { To } \\
\text { develop }\end{array}$ & $\begin{array}{l}\text { Improve the } \\
\text { formalization }\end{array}$ \\
\hline $\begin{array}{l}\text { Expected } \\
\text { Nature }\end{array}$ & Semi Structured & $\begin{array}{c}\text { Semi } \\
\text { Structured }\end{array}$ & Structured & Structured & $\begin{array}{c}\text { Semi } \\
\text { structured }\end{array}$ \\
\hline
\end{tabular}

\section{Conclusion and perspectives}

The literature has shown the existence of several attempts to adapt Eco-design methods through the TRIZ tools. However, this work presents ECOFAIRE's first adaptation attempt in this direction. This study aims first to characterize ECOFAIRE according to a model that we have developed by ourselves in this paper, then to state hypotheses of adaptation TRIZ tools to fill the limits of ECOFAIRE.

Several results emerge from this study. They can be summarized in the following:

- The adaptation of the 9 screens tool so that it can integrate the specificities of the design of ecological products.

- The adaptation of the EPV model of description of the TRIZ system of contradictions so that it can stand out in a structured way the conflicts to solve in the process of ecodesign.

- The emergence, through the exploratory case study of EcoDistrib, of the inadequacy hypothesis of the classical tools of the TRIZ (40 principles, the principles of separation and the TRIZ matrix) with the context of eco-design.

In light of these results and the exploratory approach conducted through the Ecodistrib case, several perspectives emerge:

- Conduct other case studies to confirm the ECOFAIRE improvement assumptions made in this work.

- Make a comparison between the eco-design methods that attempt to adapt the TRIZ tools to eco-design.

- Develop, in the case of ECOFAIRE, a tool that links the new system of contradiction to the principles set out in the eco-design wheel R1 and the checklist R2.

- Develop a tool similar to the effect pointers for the Ecodesign context. 


\section{References:}

[1] T Pavel Livotova, Arun Prasad Chandra Sekarana, Mas'udaha, Richard Lawb, David Reayc, Arailym Sarsenovaa, Shahin Sayyareha, Eco-innovation in process engineering: Contradictions, inventive principles and methods, Thermal Science and Engineering Progress, Volume 9, March 2019, Pages 5265

[2] Benjamin Tyla, Jérémy Legardeurb,c, Dominique Milletd and Flore Vallete, A comparative study of ideation mechanisms used in eco-innovation tools, Journal of Engineering Design, 2015

[3] Shqipe Buzuku, Iuliia Shnai, A systematic literature review of TRIZ used in Eco-Design, Journal of the European TRIZ Association 02-2017 (04)

[4] ECOFAIRE, https://www.ademe.fr/ecofaire-loutil,

[5] G. S. Altshuller, Creativity As an Exact Science. CRC Press, 1984.

[6] G. S. Altshuller, “Ariz,” pp. 1956-1985, 1985.

[7] F. Cappelli, F. Cappelli, M. Delogu, and M. Pierini, "Integration of LCA and EcoDesign guideline in a virtual cad framework," in Proceedings of LCE 2006, 2006, pp. 185-188.

[8] T. Sakao, "A QFD-centred design methodology for environmentally conscious product design," Int. J. Prod. Res., vol. 45, no. 18-19, pp. 4143-4162, Sep. 2007.

[9] E. Vezzetti, S. Moos, and S. Kretli, "A product lifecycle management methodology for supporting knowledge reuse in the consumer packaged goods domain," Comput. Des., vol. 43, no. 12, pp. 1902-1911, Dec. 2011.

[10] C. J. Yang and J. L. Chen, "Accelerating preliminary eco-innovation design for products that integrates case-based reasoning and TRIZ method," J. Clean. Prod., vol. 19, no. 9-10, pp. 998-1006, 2011.

[11] C. J. Yang and J. L. Chen, "Forecasting the design of eco-products by integrating TRIZ evolution patterns with CBR and Simple LCA methods," Expert Syst. Appl., vol. 39, no. 3, pp. 2884-2892, Feb. 2012.

[12] D. Russo, G. Bersano, V. Birolini, and R. Uhl, "European testing of the efficiency of TRIZ in eco-innovation projects for manufacturing SMEs," Procedia Eng., vol. 9, pp. 157-171, Jan. 2011.

[13] J.-R. Chou, "An ARIZ-based life cycle engineering model for eco-design," J. Clean. Prod., vol. 66, pp. 210-223, Mar. 2014.

[14] C. Liu and J. L. Chen, "Development of product green innovation design method," in Proceedings Second International Symposium on Environmentally Conscious Design and Inverse Manufacturing, 2001, pp. 168-173.

[15] D. Russo, D. Regazzoni, and T. Montecchi, "Eco-design with TRIZ laws of evolution," Procedia Eng., vol. 9, pp. 311-322, 2011.

[16] R. Vidal, J. L. Salmeron, A. Mena, and V. Chulvi, "Fuzzy Cognitive Mapbased selection of TRIZ (Theory of Inventive Problem Solving) trends for ecoinnovation of ceramic industry products," J. Clean. Prod., vol. 107, pp. 202 $214,2015$. 